\title{
A political ecology of aviation and development: an analysis of relations of power and justice in the (de)construction of Nepal's Second International Airport
}

\author{
Hanna Geschewski ${ }^{1}$ a, b \\ Mine Islar ${ }^{c}$ \\ ${ }^{a}$ Chr. Michelsen Institute, Norway \\ ${ }^{\mathrm{b}}$ University of Bergen, Norway \\ ${ }^{c}$ Lund University Centre for Sustainability Studies (LUCSUS), Sweden
}

\begin{abstract}
In this article, we investigate socio-ecological conflicts surrounding the proposed Second International Airport project near Nijgadh, a town in the southern Terai region of Nepal. Praised by the Nepali government as a gamechanger for Nepal's economy, it has come under scrutiny by environmental activists after plans emerged for extensive clearing of the densely forested project site. While public and political debates have focused on the environmental impacts of the project, the area is also home to nearly 8,000 people, most of whom have no formal land rights and belong to Janajati groups, who face displacement. The apparent lack of attention to the project's consequences for local communities raises questions about the safeguarding of their interests. Drawing on justice theories and political ecology, we conducted a case study to investigate the residents' struggle for justice, recognition, and visibility amidst a strong dichotomy of mainstream developmentalist and conservationist discourses. During two months of fieldwork in Nepal, we gathered empirical evidence, including observations, interviews, and project documentation. Our findings suggest that the misrecognition of local communities, particularly in Tangiya Basti, began long before the airport project, and is intertwined with distributive and procedural injustices, reinforced by power asymmetries of various kinds. Overall, we argue that while the airport project is often framed as an environmental conflict, it is also a conflict over claims to social justice and livelihood security.
\end{abstract}

Keywords: justice, political ecology, recognition, developmentalism, land rights, Nepal

\section{Résumé}

Dans cet article, nous étudions les conflits socio-écologiques entourant le projet de deuxième aéroport international près de Nijgadh, une ville située dans la région du Teraï au sud du Népal. Le gouvernement népalais a fait l'éloge de ce projet, qu'il considère comme un facteur de changement pour l'économie du pays, mais il a fait l'objet d'un examen minutieux de la part des activistes environnementaux après l'apparition de plans de défrichage extensif du site du projet, densément boisé. Alors que les débats publics et politiques se sont concentrés sur les impacts environnementaux du projet, la zone abrite également près de 8000 personnes, dont la plupart n'ont aucun droit foncier officiel. Ces groupes de Janajati risquent d'être déplacés. Le manque apparent d'attention aux conséquences du projet sur les communautés locales soulève des questions quant à la sauvegarde de leurs intérêts. En nous appuyant sur les théories de la justice et de l'écologie politique, nous avons étudié la lutte des résidents pour la justice, la reconnaissance et la visibilité dans un contexte de forte dichotomie entre les discours dominants sur le développement et la conservation. Pendant deux mois de travail sur le terrain

\footnotetext{
1 Hanna Geschewski, Doctoral Researcher, Chr. Michelsen Institute and University of Bergen, Norway. Email: hanna.geschewski "at" cmi.no. Dr. Mine Islar, Associate Professor (Sustainability Science), Lund University Centre for Sustainability Studies (LUCSUS), Lund University, Sweden. Email: mine.islar "at" lucsus.lu.se. The authors would like to express our sincere gratitude to the residents of Tangiya Basti, Kathgaun, and Matiyani Tol for sharing their stories and knowledge with us. We also thank Dr. Dil Bahadur Khatri, Kaustuv Neupane, and Dr. Sabin Ninglekhu for their valuable feedback. Lastly, we thank the journal editor and the anonymous reviewer for their constructive comments.
} 
au Népal, nous avons recueilli des preuves empiriques, notamment des observations, des entretiens et des documents relatifs au projet. Nos résultats suggèrent que la méconnaissance des communautés locales, en particulier à Tangiya Basti, a commencé bien avant le projet d'aéroport, et qu'elle est entrelacée avec des injustices distributives et procédurales, renforcées par des asymétries de pouvoir de différentes sortes. Dans l'ensemble, nous soutenons que si le projet d'aéroport est souvent présenté comme un conflit environnemental, il s'agit également d'un conflit sur les revendications de justice sociale et de sécurité des moyens de subsistance. Mots clés : justice, écologie politique, reconnaissance, développementalisme, droits fonciers, Népal

\section{Resumen}

En este artículo, investigamos los conflictos socioecológicos que rodean la propuesta de un Segundo Aeropuerto Internacional cerca de Nijgadh, una ciudad en la región de Terai, al sur de Nepal. Elogiado por el gobierno de Nepal como un cambio de juego para la economía del país, este proyecto ha sido objeto de escrutinio por parte de activistas ambientales después de que surgieron planes para realizar una tala extensa en el sitio del proyecto, el cual es densamente boscoso. Aunque los debates públicos y políticos se han centrado en los impactos ambientales del proyecto, el área también alberga a casi 8.000 personas, la mayoría de las cuales no tienen derechos formales sobre la tierra y pertenecen a grupos Janajati, quienes se enfrentan al desplazamiento. La aparente falta de atención a las consecuencias del proyecto para las comunidades locales plantea dudas sobre la salvaguardia de sus intereses. Basándonos en las teorías de la justicia y la ecología política, llevamos a cabo un estudio de caso para investigar la lucha de los residentes por la justicia, el reconocimiento y la visibilidad en medio de una fuerte dicotomía entre los principales discursos de desarrollo y conservación. Durante dos meses de trabajo de campo en Nepal, recopilamos evidencia empírica, incluidas observaciones, entrevistas y documentación del proyecto. Nuestros hallazgos sugieren que el desconocimiento de las comunidades locales, particularmente en Tangiya Basti, comenzó mucho antes del proyecto del aeropuerto y está entrelazado con injusticias distributivas y procesales, reforzadas por asimetrías de poder de varios tipos. En general, argumentamos que, si bien el proyecto del aeropuerto a menudo se enmarca como un conflicto ambiental, también es un conflicto sobre reclamos de justicia social y seguridad de los medios de subsistencia.

Palabras clave: justicia, ecología política, reconocimiento, desarrollismo, derecho a la tierra, Nepal

\section{Introduction}

Nijgadh International Airport is [a] project of vital importance for Nepal. This is our national pride project. This will be a game-changing project for Nepal's economic prosperity.

Rabindra Adhikari, Late Minister of Culture, Tourism and Civil Aviation, Government of Nepal (Paudyal \& Koirala, 2018)

While calls to reduce air travel have entered mainstream discourses in many high-income countries (Jacobson et al., 2020; Timperley, 2019), landlocked Nepal still has only one international airport. Blaming Nepal's poor air connectivity as a major barrier to increased tourism and economic activity, demands for building an alternative to Tribhuvan International Airport (TIA) are increasing (Sah, 2019). After years of deferment, in 2015 the Government of Nepal (GoN) revived its 1995 plan to construct an international airport near Nijgadh, a town $60 \mathrm{~km}$ south of Kathmandu (D. P. N. Pradhan et al., 2019). The project has since been promoted as Nepal's guaranteed path to development and prosperity; both themes are deeply entrenched in

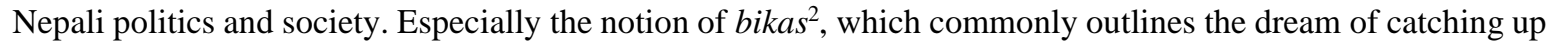
with the 'West', has prevailed for decades (Mulmi, 2018; Paudel, 2016; Pigg, 1992, 1993). In line with hegemonic development discourses, promoting economic growth and infrastructure expansion (Nightingale \& Ojha, 2013), airport proponents have highlighted the economic opportunities it offers: it is estimated to serve 27 Asian countries and generate 100,000 direct and indirect jobs (Sah, 2019).

\footnotetext{
${ }^{2}$ Nepali translation of 'development.'
} 
But similar to other large infrastructure projects (Robbins, 2011), the construction of Nepal's Second International Airport, hereafter referred to as $\mathrm{SIA}^{3}$, is not without socio-environmental consequences, also reflected in its listing as an infrastructure conflict in the Global Atlas of Environmental Justice (EJAtlas) (Bridger, 2019). The proposed construction site comprises a dense sal (Shorea robusta) forest, known to be an elephant migration corridor (Shah, 2019; Shahi, 2019). After the project's Environmental Impact Assessment (EIA) was published in 2018, many expressed shock at the prospect of cutting downover 2 million trees (A. Dhakal, 2018). Opposition formed among conservationists and environmental activists, especially in Kathmandu, and rallies and online campaigns were organized in the capital (K. D. Bhattarai, 2019b; Pro Public, 2019).

While protests and debates have focused on the ecological consequences of SIA, the project area is also home to nearly 8,000 people, most without formal land rights, who are threatened with displacement (Dhungana, 2019a; Shah, 2019). To date, the project authorities have not released a compensation and resettlement plan for the nearly 1,500 landless households. This apparent lack of public and political attention to the impact of the airport on these communities raises questions about the safeguarding of their interests. Literature shows that it is often those already marginalized who are most affected by infrastructure development (Ascher \& Krupp, 2010; Otsuki et al., 2016). Fernholz (2010, p. 225) states: "Overall, the aim of major infrastructure projects $[\ldots]$ is to improve economic growth and well-being in a country or region. Yet, many studies show that the people living in the proximate areas frequently do not share in these benefits, and often suffer major economic, health, and cultural losses."

This production of uneven landscapes in the name of development is often the result of multidimensional injustices experienced by the marginalized groups concerned (Ottinger, 2017). Exposing such injustices in the creation and alteration of socio-environments has become a growing concern of various disciplines (Schlosberg, 2013). While justice scholarship has long focused on distributive and participatory aspects, conceptualizations have since expanded to include the notion of recognition "as an inherent element of justice" and often even as the basis for the other two dimensions (Fraser, 2005; Islar, 2013, p. 41; Schlosberg, 2004, 2007).

Building on existing justice and political ecology research, such as Persson et al. (2017) and Islar (2012), in this article, we argue that the invisibility of local concerns in public debates suggests issues of misrecognition and that the conflict over SIA is as much a struggle for social justice and recognition, sustained and undermined by various manifestations of power, as it is for environmental protection. Based on empirical evidence derived from two months of fieldwork in Kathmandu and the Nijgadh area in Bara district, we examined the injustices faced by the communities affected by the airport project and how various kinds of power have manifested as identifiable injustices. This study was led by our overarching research question and three sub-questions: How and to what extent can the case of Nepal's Second International Airport be understood as a site of conflict over recognition and other related injustices? (a) What are the historical injustices regarding land use in the SIA project area? (b) What are current injustices regarding land use in the SIA project area? (c) What are the different dimensions of power embedded in the conflict and how do they reinforce injustices?

We have structured this article as follows. After introducing the background of airport project in Section 2, we discuss in Section 3 the theoretical framework based on Svarstad's work on conceptualizing power and its relevance for justice scholarship (Svarstad et al., 2018; Svarstad \& Benjaminsen, 2020). By applying a framework that draws on both theories of justice and political ecology, we hope to foster the "potential for cross-fertilization between the two fields" called for by Svarstad and Benjaminsen (2020). The authors propose applying specific conceptualizations of power from political ecology to environmental justice, which we put into practice by using a three-dimensional power structure developed by Svarstad et al. (2018) to understand issues of misrecognition and other related injustices. The fourth section explains the methodological framework and fieldwork process. Sections 5 and 6 discuss the findings in the context of power relations and historical and current injustices related to land rights and competing land uses due to the airport project. In Section 7, we

\footnotetext{
${ }^{3}$ In this article, we have chosen to use the term "Second International Airport" and its abbreviation SIA, which is commonly found in official government communication about the project. The term "Nijgadh International Airport" (NIA) also appears in the media, civil society, and some government agencies. However, its use is contentious, in part because the project area falls not within the municipality of Nijgadh but in the neighboring municipality of Kolhabi.
} 
conclude by highlighting the need to explore larger issues of reconciling community interests with sustainability and sustainable development concerns.

\section{Twenty-five years in the making}

Although often framed as being the latest mega-development initiative in Nepal, plans to build SIA have existed for nearly three decades (see Figure 1 for project map). By the 1980s, the GoN mentioned plans for a second international airport (Gautam, 2020). Discussions gained momentum in 1992, triggered by two catastrophic air crashes in Kathmandu (K. D. Bhattarai, 2019a). In 1995, the government commissioned the consulting firm Nepal Engineering Consulting Services Centre Limited (NEPECON) to conduct a prefeasibility study of eight sites, in the course of which an area west of Nijgadh was identified as the most suitable (Gautam, 2020; Lal, 2019). However, the decade-long Maoist insurgency from 1996 onwards brought the project to a standstill (Gautam, 2020). It was not until 2010 that the project-implementing agency, the Ministry of Culture, Tourism and Civil Aviation (MoCTCA), commissioned the Korean company LandMark Worldwide (LMW) to conduct a detailed feasibility study (DFS) (Shah, 2019). MoCTCA, however, never received the complete DFS, only a summary, as the government never paid for the report in full (Lal, 2019). After plans to build SIA in cooperation with LMW as well as with the later applicant Flughafen Zürich AG fell through, MoCTCA declared that it would develop the project on its own (Prasain, 2020b, 2021; K. D. Shrestha, 2020). In May 2021, however, when the state budget for the upcoming fiscal year was announced, funds were only earmarked for completing site preparation, leaving the financing of the airport project uncertain (Sunuwar, 2021).

In a separate process, the Nepali engineering firm GEOCE Consultants (P) Ltd. was awarded the contract to deliver a project EIA in 2016, and they submitted it in March 2018 (Shah, 2019). Two months later, the report was approved by the Ministry of Forests and Environment (MoFE). Interestingly, the Civil Aviation Authority of Nepal (CAAN) had already signed a Memorandum of Understanding with the Nepal Army on behalf of MoCTCA in September 2017, long before the EIA was approved, which allowed the Army to cut down trees for building roads on the proposed construction site (Golf, 2017).

The EIA, which was only published after environmental journalists filed a request in 2018 , revealed that up to 2.4 million pole-sized and mature trees worth US\$ 629 million as timber would have to be cut to clear the project area (A. Dhakal, 2018; Shah, 2019). This figure has since been corrected by officials to 328,904 trees in the first project phase (Shah, 2019). Project authorities further claim that deforestation can be offset by planting 25 saplings for each cut tree, but are yet to propose a suitable area (Lal, 2019).

Deforestation could have serious impacts on local biodiversity (Chernaik, 2019; S. Shrestha, 2018). The area is home to over 500 different bird species, 23 endangered flora and 22 endangered wildlife species (Lal 2019; S. Shrestha 2018). The forest lies within the Terai Arc Landscape and is connected to the Parsa and Chitwan National Parks. Together they form important wildlife migration corridors (NEFEJ, 2019). Thakur (2015) concluded that the area around Tangiya Basti, i.e., the airport project area, falls within three common elephant migration routes and is a highly suitable elephant habitat. The interruption of current migration routes is expected to increase the risk of human-wildlife conflicts in this area (NEFEJ, 2019). As the forest serves as a water reservoir, deforestation is also expected to deplete groundwater during the dry season, threatening drinking water supplies and irrigation for thousands of people, as well as leading to severe flooding during the monsoon season (Lal, 2019; NEFEJ, 2019). In addition, the project is expected to cause noise and air pollution and to threaten two collaborative forests adjacent to the project site, Tamagadhi and Sahajanath, whose user groups have 37,000 beneficiaries that depend on forest resources for their livelihoods (NEFEJ, 2019; Shah, 2019).

The release of the EIA was followed by criticism from various groups, including forest experts, lawyers, environmental activists, and journalists. In addition to the ecological impacts, many questioned the excessive size of the proposed airport, arguing that other international aviation hubs are significantly smaller than the 
allocated 8,046 hectares ${ }^{4}$ (B. Bhattarai, 2020; S. Shrestha, 2018). Opponents further alleged that the selection of Nijgadh was influenced by political agendas and that alternative sites were not adequately explored (S. Shrestha, 2018). The EIA itself also came under criticism for containing misleading information after parts of it were found to have been copied directly from an earlier EIA produced for a hydropower project ${ }^{5}$ (Gautam, 2020; Mandal, 2020). Building on this criticism, two Public Interest Litigations (PILs) were filed in 2019 against MoCTCA, MoFE and the Prime Minister's Office, among others, by groups demanding the review of alternative sites and the preparation of a new EIA (Awale, 2020; T. R. Pradhan, 2019). At the same time, the petitioners and other environmental activist groups organized protests across Kathmandu and raised awareness on social media (Bachmann, 2019).

In response to the petitions, on 6 December 2019 the Supreme Court of Nepal a suspension of project activities forward until the ambiguities regarding its impacts are resolved (T. R. Pradhan, 2019). After extending the stay order on 22 December 2019, Chief Justice C.S. Rana stated: "The court should be equally responsible toward the earth, trees, aquatic animals and birds" ("CJ Rana", 2020; Prasain, 2020a). To date, the stay order has not been lifted, in part because the assigned Chief Justice Rana came under criticism for alleged corruption in 2021, which in turn led to fellow judges refusing to serve on his bench (Ghimire, 2022). Irrespective of the absence of a final decision by the Supreme Court, newly appointed Prime Minister Sher Bahadur Deuba presented an updated overall plan for the project on January 6, 2022, stressing that construction should not be delayed any further ("Construction of Nijgadh Airport should not be delayed", 2022).

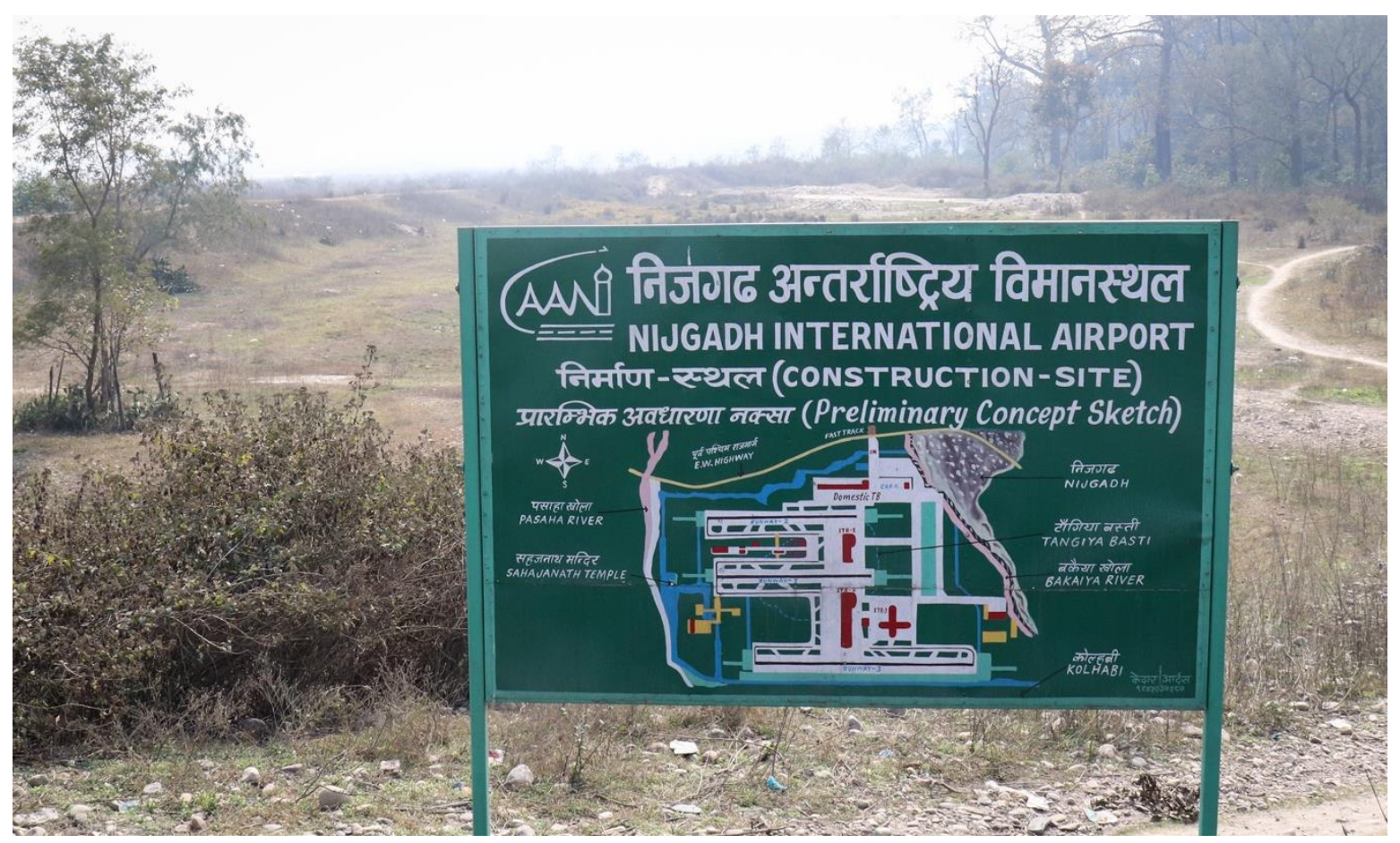

Figure 1: Information board next to East-West Highway, outlining the airport project area. Source: Authors, 2020.

\footnotetext{
${ }^{4}$ The New Bangkok International Airport (Suvarnabhumi), Indira Gandhi International Airport in Delhi and the Singapore Changi Airport cover areas of 3,240 ha, 2,066 ha and 1,300 ha respectively (S. Shrestha, 2018).

${ }^{5}$ Chapter 7.3 of the EIA states: "Nepal has accorded high priority for the development of hydro-electricity project(s) (...). The project will generate environment-friendly clean energy and will contribute to the socio-economic development of the country"(GEOCE, 2018, p. 7.2).
} 


\section{Justice and three-dimensional power}

Environmental justice and political ecology serve as the theoretical umbrella of this study, building on the growing body of literature linking justice and political ecology concepts (Domènech et al., 2013; Gonzalez, 2019). Svarstad and Benjaminsen (2020, p. 2) noted that there is potential for synergy especially in the notions of justice and power, due to "a lack of specification of various conceptions of 'power' in [environmental justice] literature." Thus, combining the two concepts to understand what injustices exist and examine what kinds of power manifest them seems a promising framework for analyzing the Nijgadh conflict.

We have chosen a three-dimensional environmental justice framework that includes aspects of distribution, recognition, and participation, inspired by Schlosberg (2004, 2007, 2013) and Fraser (1998, 2000, 2005), among others. Although the framework is commonly used to examine communities' claims to nature and natural resources, we believe that its grounding in social justice theory also makes it suitable for examining other justice claims put forward by communities.

First, a distributive justice perspective that focuses on how burdens and benefits are distributed in socioenvironmental interventions provides a valuable starting point for examining how local communities' livelihoods and access to land and facilities have been affected by the airport project. Following Schlosberg and others, however, we do not understand distributive injustice in isolation from misrecognition and existing power asymmetries. Second, justice as recognition provides a key lens for understanding patterns of marginalization of local communities through various institutional, social, and cultural channels. Following Svarstad and Benjaminsen (2020, p. 4), we complement recognition theory with concepts of senses of justice, defined as "ways in which affected people subjectively perceive, evaluate and narrate an issue", and critical knowledge production, which concerns access to independent information to "facilitate the expression of subaltern voices" and explore competing justice claims of affected communities, even beyond pure environmental justice claims. Third, procedural justice offers a helpful perspective, not only on how affected communities are involved in the airport project decision-making process, but it also provides insight into how they practice participation within their communities, essentially examining internal notions of power.

We understand these justice dimensions in the context of persisting power asymmetries, which we analyze using Svarstad et al.'s (2018) three-part conceptualizations of power in political ecology, encompassing actor-oriented, neo-Marxist, and poststructuralist conceptions of power. The authors put emphasis on the synergistic potential between the three to understand how power affects human-environment interactions in different ways and at different scales. In our case, they provide valuable starting points for unraveling the complexity of the SIA case, and understanding how the injustices experienced by affected communities are situated within political and sociocultural manifestations of power.

\section{Study site and methods}

The research was designed as an empirical single case study. We use the specific case of community livelihood conflicts surrounding the airport project to illustrate broader trends in development and modernization in Nepal. Most of the empirical evidence was gathered during two months of fieldwork in Nepal. Situating our study within social constructivism, we acknowledge that our positioning as white, European female researchers influenced the research process as well as our interpretation of the data. Although one of the authors speaks Nepali and both are deeply familiar with diverse aspects of Nepali society, thereby reducing socio-cultural and lingual barriers, we do not claim to establish absolute truths. Rather, we have intended to present a dense and authentic account of the complex, intersecting, and diverse realities we found in the research situation.

Our study sites included Kathmandu and areas in and near the SIA project area in Bara district, which spans 8,046 ha and is delimited by the rivers Lal Bakaiya to the east and Pasaha to the west, the East-WestHighway to the north and a fence to the south (GEOCE, 2018). Some $94.3 \%$ is forestland, while the three settlements within the project boundaries cover an area of about 500 ha (Shah, 2019). Tangiya Basti (TB) is the largest settlement, see (A) in Figure 2, and has grown to 1,476 households since its establishment in the 1970s 
(Dhungana, 2019b). Most people are migrants from the hills and belong to the Janajati ${ }^{6}$ ethnolinguistic groups of Tamang and Magar; other ethnic and caste groups are Dalit, Bahun, Chettri and Newar (Dhungana, 2019a). None of the residents have land ownership documents (Dhungana 2019a). The second largest settlement is Kathgaun (KG, see (B)) with people of various ethnicities and castes including Tharu, an indigenous group from the Terai. Of the 132 households, only 16 never owned land. Recently, however, the government acquired most of the privately-owned land through compensatory payments, leaving many without legal documents (Sah 2019). The smallest and youngest settlement is Matiyani Tol (MT, see (C)). Dalit families from other parts of the Terai began settling in the early 2000s. To date, all 40 households are landless (Shah, 2019).

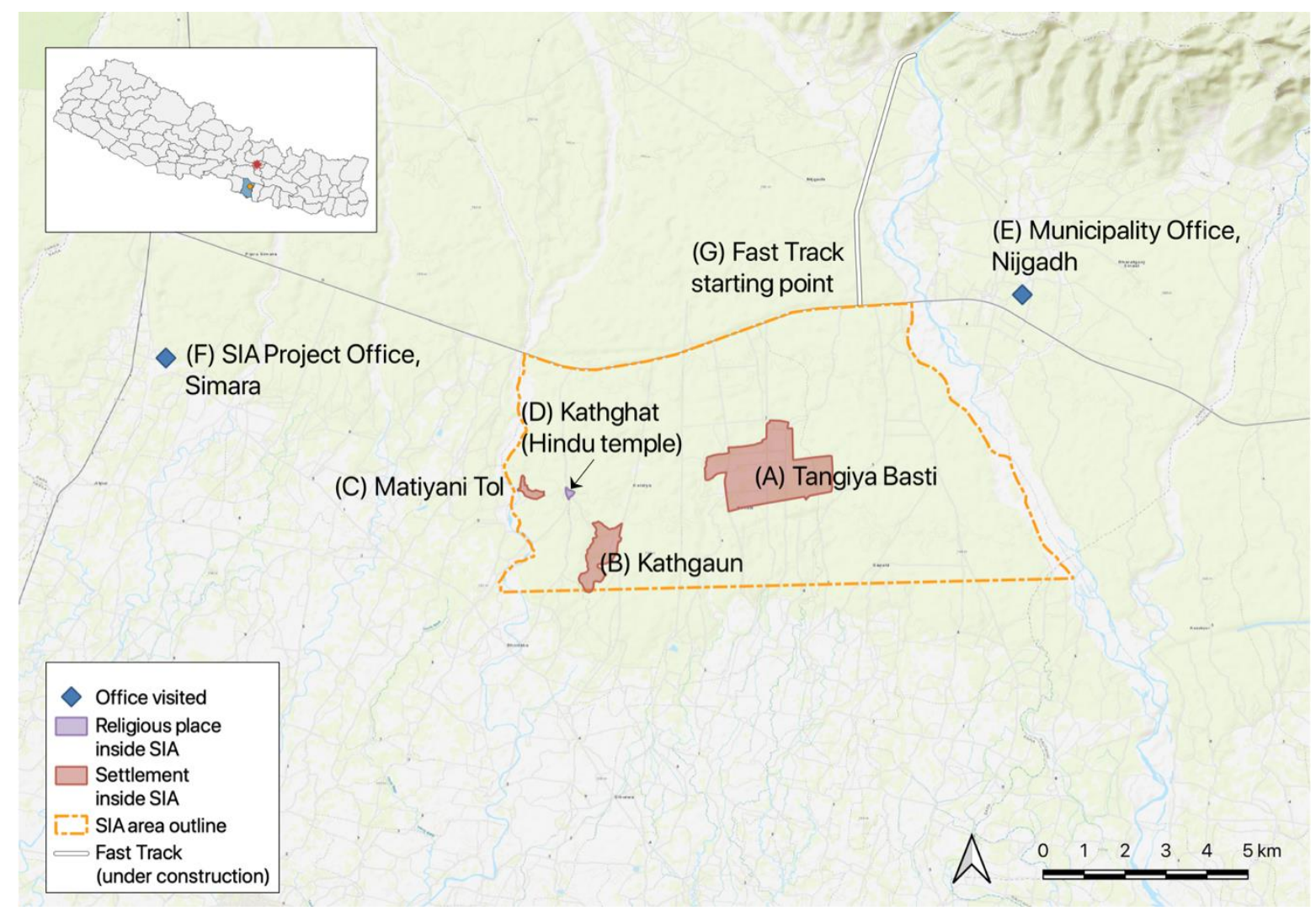

Figure 2: The study site in Bara district with the proposed SIA construction site. Source: own creation based on fieldwork, DIVA GIS data and printed map provided by SIA Project Office.

As befits a case study, we used multiple sources of evidence to account for the complexity of the case and to facilitate convergence through triangulation (Yin, 2009). We collected primary data through observations and semi-structured interviews with residents from the three directly affected settlements (TB, KG, MT). To gain a deeper insight into local dynamics, we decided to focus on Tangiya Basti, where we conducted most of our interviews with residents, and to visit Kathgaun and Matiyani Tol for only one group interview each. We also interviewed local politicians and project officials, expert interviews with Kathmandu-based activists, lawyers, and environmental scientists with knowledge of the case. We also drew on secondary data in the form of project documents, legal and policy documents, and media reports. After transcribing and translating the interviews, we coded them to identify themes and patterns. This was done deductively and inductively, as our

\footnotetext{
${ }^{6}$ Heterogeneous groups with their own culture, language, religion, and customs, which make up 35.6 percent of Nepal's
} population and do not fall into any of the categories of the Hindu Varna system (Jha, 2019). 
analysis was informed by theories of justice and power, but we also sought to identify new perspectives to capture the lived experiences of the respondents.

\section{Past and present injustices of recognition}

Our study of injustices faced by residents of the three affected settlements is based on the understanding that community-level injustices are embedded in wider historical and present framings of land rights, land ownership, community, and access to basic facilities in Nepal. Recognizing that there is a link between community-level injustices and national-level development (bikas) narratives, we begin our analysis by situating our case within broader discourses of development and modernization in Nepal.

The longing for bikas has shaped the idea of the Nepali nation state for years (Kramer, 2008; Pigg, 1992). While many consider the early 1950s, marked by the fall of the Rana dynasty and the emergence of foreignfunded aid initiatives, as the beginning of modern development ideologies in Nepal, the rhetoric of prosperity and progress has been prevalent since Nepal was unified under the Shah dynasty in the 18th century (Paudel, 2016; Pigg, 1992).

As scholars have noted, development in Nepal is more than common concepts of 'empowerment' and 'modernization' (Kramer, 2008; Pigg, 1992; Saxer, 2013). Rather, it is "the overt link between [Nepal] and the West"; a national vision of hegemonic superiority, deeply entrenched in the imagination of society and omnipresent in radio, TV, and schoolbooks (Ahearn, 2004; Pigg, 1992, p. 497; Sharma, 2002). This has created a dichotomy between what is desired and what is not: urban vs. rural, educated vs. illiterate, the West vs. presentday Nepal (Rest, 2012). As Pigg states, "where there is a push for progress through development, there is the creation of a state of backwardness" (1993, p. 46).

Although the understanding of bikas is not homogenous, it is often expressed in material terms, as tangible facilities (suvidha) (Murton \& Lord, 2020; Nightingale, 2017; Pigg, 1992). Influenced by Western interpretations of development as technological progress, industrialization, and growth (Escobar, 1995), infrastructure expansion for improved connectivity and economic activity is a major pillar of Nepal's "development dream" (Campbell, 2010; Murton \& Lord, 2020, p. 3). In the National long-term goals of the 15th Five-Year Plan, which outline the path to the GoN's vision "Prosperous Nepal, Happy Nepali"7, "Accessible modern infrastructure and intensive connectivity" is listed as a key goal for prosperity (National Planning Commission, 2020, p. 19). More specifically, the plan includes ten large transport infrastructure projects as part of twenty-two 'National Pride Projects'; SIA is one of these.

While there is a need for improved mobility in Nepal, research shows that large-scale infrastructure often leads to the production or consolidation of uneven landscapes, e.g., conceptualized as power corridors, leaving hopes for improved livelihoods unfulfilled for many (Campbell, 2010; Murton \& Lord, 2020). The following sections take a closer look at how uneven landscapes have been produced in the case of SIA and how communities and their desire for development have been compromised in the name of national prosperity.

\section{A lack of land ownership}

Tangiya Basti was established in 1974-75 and has since grown to 1,476 households with around 7,500 inhabitants. While basti translates to 'settlement' in Nepali, tangiya points to the origins of the village as it is derived from taungya, a Burmese term (taung $=$ hill and $y a=$ cultivation) that describes a type of shifting cultivation in agroforestry (Bhusal, 2010). Sources mention that the taungya system was introduced in Nepal in 1972-74 in the Tamagadhi area near Nijgadh, suggesting that the founders of Tangiya Basti were some of the first in Nepal to apply it (Adhikari \& Poudel, 2018; Gahatraj, 2017).

In taungya, agricultural crops were grown along with tree saplings, mainly Dalbergia sissoo and teak, on degraded state-owned forestlands (Amatya, 2018). After three to five years, when the tree canopy began to cast excessive shade, cultivation was shifted to another, nearby location (Ndomba et al., 2015). As one villager in TB remembers: "We came here to do tree plantation [...] We grew sisau trees. For example, we sowed maize

\footnotetext{
${ }^{7}$ The slogan Samriddha Nepal, Sukhi Nepali was introduced by former Prime Minister K.P. Sharma Oli in a speech during a state visit to India in 2018 (Ministry of External Affairs, 2018).
} 
and mustard, we ate that. And when the trees grew, we moved." The system was a cheap and effective way to manage forests while providing a livelihood for the planters, who were mainly victims of natural disasters and landless peasants from hill districts (Bhusal, 2010; Ojha, 1983). A villager from TB confirmed:

[We came] in $2032 \mathrm{BS}^{8}$ [1975/76 AD]. The reason was, there was a landslide in the upper region, and we lost most of our land. [...] People affected by the flood, who didn't have land or houses anymore came here.

The emergence of multi-party democracy in 1990 ultimately led to changes in Nepali forest policy and the abolition of taungya (Ninglekhu, 2020; Wagley \& Ojha, 2002). Despite initial promises by authorities, planters who had lived in huts around the forest until then received neither land ownership certificates (lalpurja) nor alternative land plots. In the absence of any government interference or support, they began to establish a permanent settlement in Tangiya Basti (personal communication; GEOCE, 2018). A villager reminisced:

Our forefathers were told, "You will be employed as laborers to raise saplings and farm the land $[\ldots]$, and once the government stops employing this system [...], we will arrange land for you permanently." [...] But once we had democracy, the government didn't move us anywhere, nor did they give us land ownership. Since then, we've been here.

Later, during the 10-year long Civil War (1996-2006), the TB forest was a hiding spot for armed Maoist rebels who were controlling large parts of rural Nepal at the time. The Maoists taught the villagers to build more durable structures using timber from the forest. During this period, the TB population increased considerably. Two years after the end of the war, the Maoists won the 2008 assembly elections. Officials soon imposed a permanent ban on taking timber from the TB forest; but still no arrangements for permanent tenure were made.

The denial of formal land rights to the TB population appears to be the first and possibly most significant case of their nonrecognition, long before the airport project was launched, and it had direct distributive implications. In Nepal, land ownership is an important determinant of wealth, power, and social status, or as Dhakal (2011, p. 1) states: "Land is probably the most important asset in the rural-agrarian economy." A land certificate is the key to access to services and socio-economic security (Wickeri, 2011), and a lack thereof renders people marginalized and unable to carry out simple procedures, as one shopkeeper in TB explains: "It is difficult to do anything here because we don't have permanent residence. [...] I cannot register for any business because this place is a temporary residence."

But people in TB are not only administratively marginalized, but they also face misrecognition as they are seen by many as illegal encroachers of the land they have inhabited since the 1970s. In an informal conversation with a staff member at the SIA Project Office in Simara, after we explained that we were investigating the impact of the airport on local communities, he replied: "Are they affected or are they the effect?", implying that they have been exploiting forest resources. Similarly, one of our interviewees in Kathmandu from an ecologically motivated airport opposition group stated:

I see [TB residents] as encroachers of the forest land, although the government [...] might have kept them in that place [...], because a person should know that being on forest land is an enclosure $^{9}[\ldots]$ ignorance of the law is no excuse.

An environmental activist we interviewed in Kathmandu reported similar reactions during a panel discussion with environmental experts on the SIA project:

\footnotetext{
${ }^{8}$ Bikram Sambat, the official calendar in Nepal, is 56.7 years ahead (in count) of the solar Gregorian calendar.

${ }^{9}$ Here, 'enclosure' is to be understood as 'encroachment' or 'appropriation'.
} 
[The experts] said, [TB residents] are like leeches. [...] They are the ones that came and took over the forest, destroyed it, cleared everything, and destroyed more so they need to be taken out of there. [...] I was really taken aback.

These reactions not only disregard that the Nepali leadership was instrumental in the encroachment of the forest under the taungya program and the founding of TB through promises of permanent settlement and later neglect, but they also show how the residents are socially stigmatized, as one TB resident expressed: "They discriminate against us as if we were outsiders. As if we came off our own accord, but we did not do that. The government brought us here. King Birendra was the ruler back then."

\section{A lack of recognition as a community}

While the misrecognition of local communities began before the launch of the airport project, SIA has been an essential part of TB's history. Many respondents had heard about plans to build an airport over two decades ago. Some remembered that officials came to the village in 1995 as part of NEPECON's pre-feasibility study of potential airport sites (see Section 2): "They dug some soil, but nothing was fixed. [...] They came here to check if the land is okay to build the airport." After the Civil War had halted the project, a delegation led by the former Minister of Culture, Tourism and Civil Aviation, Prithvi Subba Gurung, returned to TB in 2008 to announce SIA's resumption. This was the first time that the government had provided residents with project information and inquired about their opinions. Yet the meeting was also used to underline the finality of the project, making the enquiry into the community's concerns appear to be mere tokenism, as one TB resident remembered: "He came with five ministers and requested us to not hinder the development process. [...] He told us that the airport will be built and that it has already been announced nation-wide."

The exclusion of residents from the early SIA project decision-making process is not just an injustice in itself, as defined by Young (2002), it also illustrates the interplay of procedural, recognitional and distributive justice dimensions. Preventing the locals to "participate on a par" in the project planning is an expression of their nonrecognition and social subordination with implications for their distributive equity (Fraser, 2000, p. 113). Their socio-economic status as a landless migrant population undermines them as equal rights holders in Nepali society ${ }^{10}$; showing the circularity of recognition and participation: "If you are not recognized you do not participate; if you do not participate, you are not recognized" (Schlosberg, 2007, p. 26). Young (2002, p. 34) extents this to democracy and justice - where one is an element but also a condition of the other - and argues that where structural injustices exist, "formally democratic procedures are likely to reinforce them."

\section{A lack of access to basic facilities}

Due to its informal status, the people of TB have been largely excluded from rural development initiatives. Thus, many residents actually reacted positively after the airport plans surfaced in 1995, hoping to finally gain access to basic facilities, such as electricity. But instead, SIA soon proved to be the main reason why basic services were not made available for $\mathrm{TB}$, as a member of the TB concern committee explained:

After the state decided to build the airport, everything was stopped [...]. We need a [electricity] line, roads, irrigation, health services, drinking water. We have been asking for these since the beginning. But the government has ignored us, saying that since an airport is going to be built, why should the state spend money?

\footnotetext{
${ }^{10}$ This does not mean that official land titles protect rural people from marginalization, as can be seen in the case of Kathgaun (KG) where most of the c.110 land-owning households sold their land titles to the government and now claim that they are unable to acquire new land large enough to sustain themselves, due to insufficient compensation payments. Nevertheless, their legal ownership of the land required the SIA project officials to involve them in talks on compensation much earlier than the landless TB community.
} 
This reasoning was confirmed by a SIA project official in Simara: "We cannot build the airport without removing the village. Knowing this, investing in facilities for the village is a waste. [...] The focus should be on faster resettlement rather than providing facilities." Similarly, a local politician stated: "We know that the people in Tangiya Basti need facilities, be it water for farming, electricity or shelter, but we cannot ignore that this is double expenses since they have to be resettled." While these responses appear rational and solutionoriented, they neglect the temporal scale of the struggle, as TB residents were advocating for access to facilities long before the airport gained public momentum.

Contrary to nearby villages, TB is still not connected to any major electricity grid and residents rely on 60 to 100-Watt solar panels for basic lighting and phone charging (Figure 3). Drinking water is supplied through around 50 taps that were installed with government support in the early 1990s, but according to residents, it is of poor quality and fetching it is strenuous. Similarly, education services have been stagnating due to the government's apathy, as a villager explained: "There are only three schools. One runs up to grade 8 , the other is up to 5 , and one is a boarding school. [...] we could run +2 levels ${ }^{11}$, but the government doesn't allow us to progress."

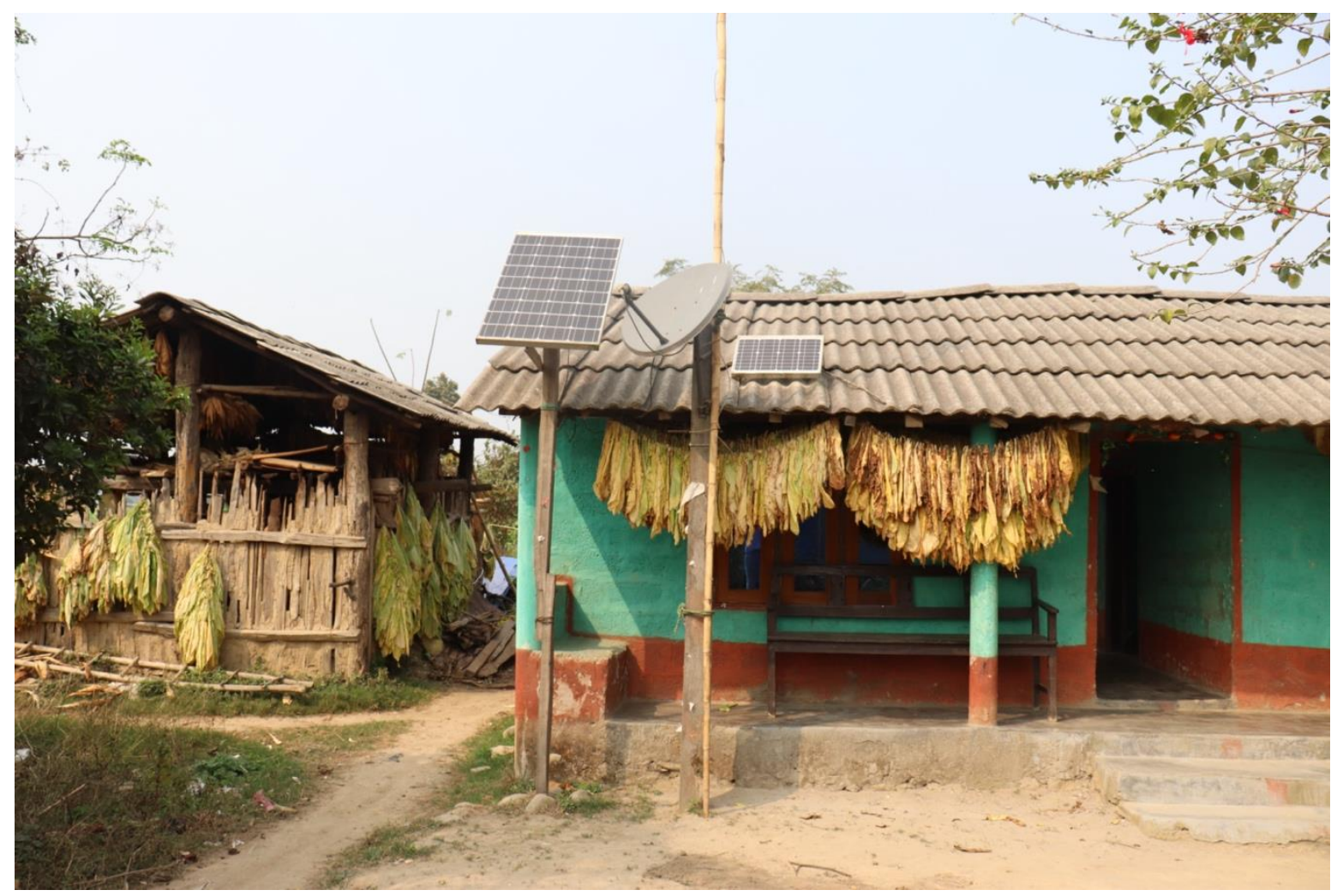

Figure 3: Small solar panels commonly used by households in Tangiya Basti for energy supply.

Source: Authors, 2020

In the absence of adequate support, TB residents have taken the initiative to build infrastructure themselves, often with financial support from relatives working abroad. A striking example of such collective action is the village irrigation system, see Figure 4, which has enabled people to improve their livelihoods through the commercial cultivation of bananas and tobacco, among others: "We have built all the irrigation

\footnotetext{
${ }^{11}+2$ level includes Grade 11-12 and is completed with the Higher Secondary Certificate (required for university admission).
} 
facilities with our own money. We created groups of 15 to 20 households, and one household would invest 40,000 to 50,000 rupees." (US\$ 330-415) However, while the government has long stood idly by and initially even encouraged community-driven initiatives in $\mathrm{TB}^{12}$, it has increasingly hindered local efforts: "They don't even allow renovating a collapsing house and tell us to stop building, because the land has already been taken by the Ministry of Tourism."

Given the continued stagnation, many respondents wished for a timely end to their limbo, with or without the airport: "It is only a loss if we remain in this state of pendulum", one said. This contrasts with the interest of airport critics in Kathmandu, who are hoping for a further delay of the project, as one activist explained: "For us it is good. The more we can wait, the more discouraged investors will be, the more attention this project will get."

From our initial observations, TB appeared to be a quaint agrarian village. But what at first glance seemed picturesque is a reflection of the harsh reality of life for the residents, where community development has been hindered in the name of national development. In fact, TB's infrastructural deprivation illustrates that the impact of the SIA project began to unfold over two decades ago. The state of uncertainty has shaped the history of TB, leading to limited access to education, communication, and secure shelter. Once again, the nonrecognition of the villagers and their needs had direct distributive consequences, leading to their continued marginalization.

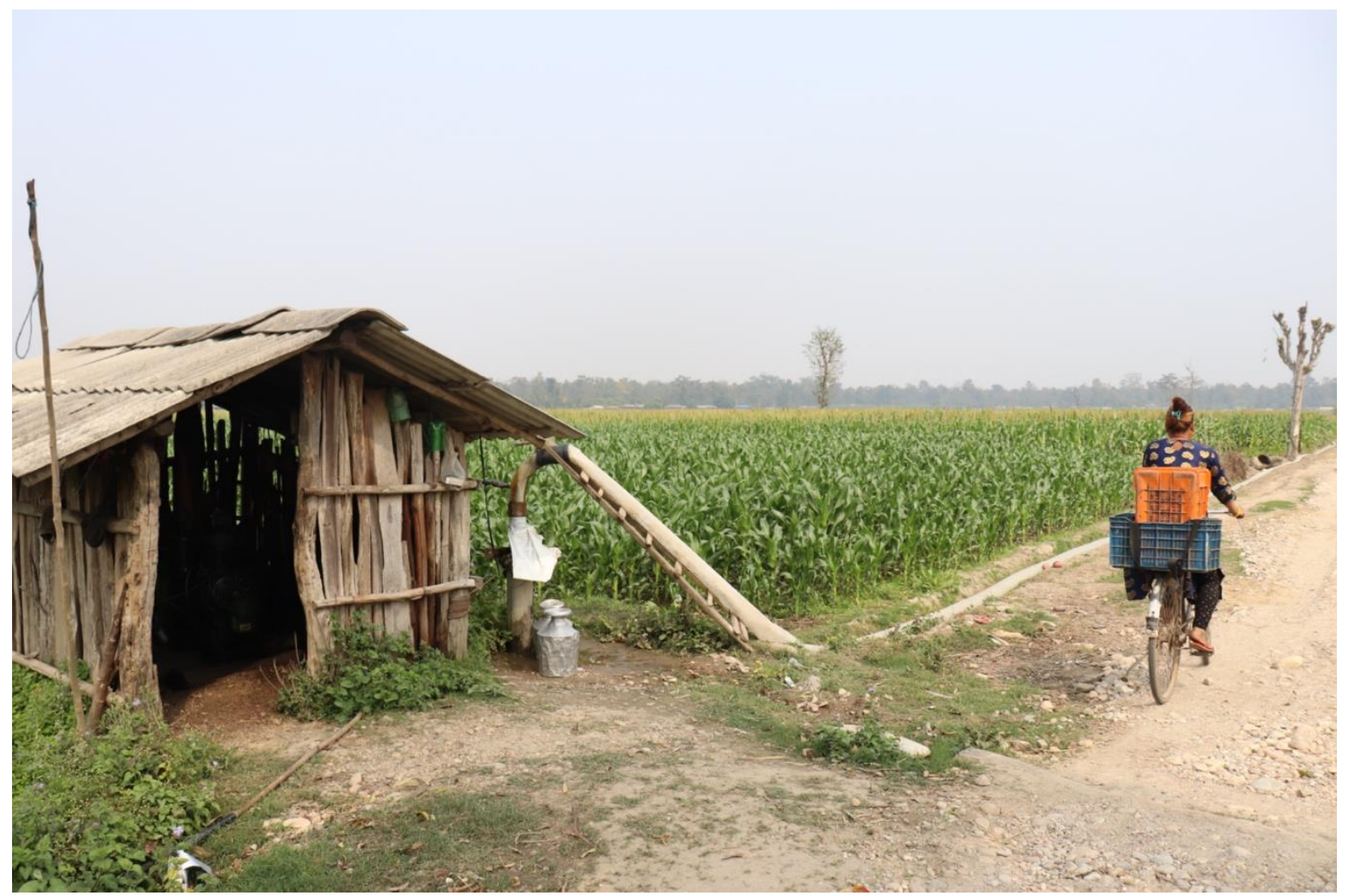

Figure 4: Pump and line as part of village irrigation system. Source: Authors, 2020

\footnotetext{
${ }^{12}$ For example, through the rural development scheme 'Build Your Village Yourself' under Prime Minister Adhikari in 1994-95.
} 


\section{A lack of consultation and access to independent knowledge}

After 25 years of planning the airport, fast forward to 2020. According to media reports and a SIA project official, the preparatory work preceding the first project phase is nearing completion (Rai, 2019). One of the most visible results is a fence, Figure 5, consisting of concrete pillars and wire, that encloses the three settlements, Kathghat Temple, access roads, and which also marks the southern border of the project site. As the fence's purpose was not clear to us, we asked our respondents about it, only to find out that they too were not sure, as officials had never informed them: "We don't know. They said it's for the airport. Then again, they have to destroy the fences once they start to build the airport." One respondent said she had to ask the authorities to cut passages for households that still do not have a toilet - and are reluctant to invest in one because they may be relocated - and defecate in the forest. The fence exemplifies the sluggish flow of information concerning the airport project and the insufficient consultation with residents, which could have prevented the toilet issue, for example.

Although the EIA (GEOCE, 2018, p. 2.7) states that "Public Consultation was sought at different stages of EIA report preparation", the only formal consultation that our respondents mentioned was a public hearing in Simara on 31 August 2017. Its purpose was "to inform the local people about the environmental implication of the projects and to collect the opinions, suggestions and recommendations from the local institutions, local bodies and people" (GEOCE, 2018, p. 2.7). Nevertheless, the choice of the location around $25 \mathrm{~km}$ from TB suggests that the hearing was not intended to reach the entire population but was mainly aimed at community leaders and village elites. In fact, most interactions with authorities seem to take place through the local Tangiya Basti Concern Committee (TBSS), which acts as a representative body of all three settlements on SIA issues.

This is not to say that people of TB have no contact with government members. Many responded that officials frequently visit to speak about SIA or, as one villager put it, "I don't think there is a minister who has not come here yet." On 17 November 2019, the current Tourism Minister Yogesh Bhattarai made a stopover in $\mathrm{TB}$, during which he announced the completion of SIA within five years and promised the villagers a swift solution for their resettlement - "We believed him, thought he was going to build it then and there. But nothing has happened till now." Despite growing disillusionment, statements like Bhattarai's still have an undeniable effect on people: "When a person like that tells us something, we are born to believe them."

Several respondents said that the presumed interest of politicians in TB is mainly due to its value as a vote bank ${ }^{13}$ : "During election time [...] they run from house to house begging for votes." But despite this awareness, limited access to alternative sources makes it difficult to evaluate the information provided by officials: "We only repeat what we hear." This dependence on information produced and reproduced by dominant actors such as the government is considered an injustice in Svarstad and Benjaminsen's (2020) concept of critical knowledge production. The ability of marginalized groups to access independent knowledge about the project, its impacts, and actors is understood as a crucial justice dimension in environmental interventions.

Many responded that they seek information about the project through radio, newspapers, social media or the TBSS (Tangiya Basti Concern Committee). However, print media have limited importance because firstly, they do not report sufficiently on issues relevant to the communities and secondly, mainly reproduce statements by dominant actors. The TBSS, on the other hand, appears to be a powerful source of information, because several of its members stated to have personal contacts in government offices and political parties who provide them with updates on SIA:

We contact our friends in Kathmandu. [...] Some of them are leaders who are close to the politicians. [...] that's how we know what's going on [...] We don't get informed by the Simara [SIA project] office, we usually get the information from our friends.

\footnotetext{
${ }^{13}$ A South Asian concept of a group of people who can be relied upon to vote together in support of the same party (Breeding, 2011; Srinivas, 1951).
} 


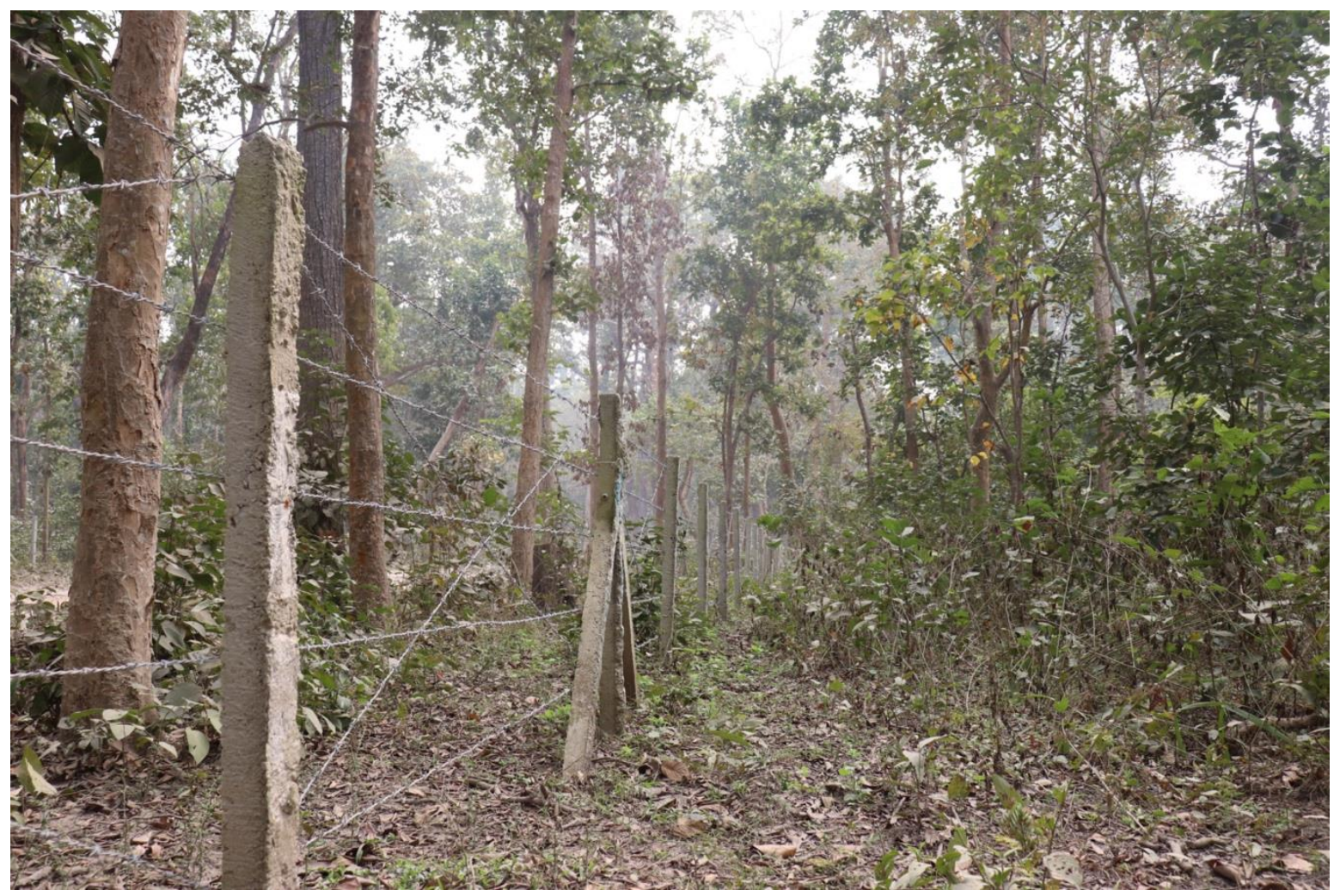

Figure 5: Fencing along the connecting road from East-West Highway to Tangiya Basti. Source: Authors, 2020

The TBSS was established in 2008 in response to the resumption of SIA and has since had three chairpersons, including the current one, a Bahun ${ }^{14}$ and a former teacher. In March 2020, the TBSS had 17 members, male and female, from almost every $t^{15} l^{15}$ of TB. People from KG and MT also occasionally take part in TBSS meetings. Although the TBSS effectively gathers information and channels the villagers' interests as a seemingly unanimous voice to appeal to the authorities, it also acts as a 'filter' through which information must flow before it reaches the rest of the community, which again restricts access to truly independent information, as advocated by Svarstad and Benjaminsen (2020).

Moreover, it is striking that in a village with less than 15\% upper-caste households, the first and current committee chairmen are Bahun. This suggests that caste is still a strong determinant of the socio-political power distribution in the community. Historically regarded as the ruling caste, until date bahuns have the highest literacy rates and civil service representation in Nepal (Malla, 2018). Nightingale $(2005,2010)$ shows that the perceived intellectual superiority of high castes continues to lead to social stratification at community level, partly maintained by Bahuns themselves and partly through complex processes of internalized subalternity of lower castes. One villager, a Tamang, justified the Bahun leadership by saying: "He's speaking for this place, for us and no one is as intelligent as him. [...] He is a son of Bahuns and is like no other." With regards to the TBSS election process, another Tamang villager said: "We had a meeting, and we chose the people who could talk well."

\footnotetext{
${ }^{14}$ Nepali for Brahmin, i.e., highest caste in the Hindu varna system.

${ }^{15}$ Nepali for town quarter, square or junction.
} 
In the above statements, caste and perceived intellect are used to justify the Bahun leadership of the TBSS, which in turn acts as the community's leading voice. The perceived superiority of educated (high-caste) actors comes with the perceived inferiority of less educated (low-caste) actors and an internalized notion of backwardness. When we asked a villager, a Magar, how aware TB residents were about the airport project and its potential impacts on their livelihoods, he responded: "People are not really interested in the airport. This is a Matwali ${ }^{16}$ settlement. [...] Matwalis are straight people. They don't show much interest in these things." Again, caste is directly linked to behavior and intellect. Seven out of 13 interviewees in TB described their community as uneducated. The subordination extends further to the relation with the authorities: "We aren't as educated as [the project authorities]" and "We can only listen; we don't really say anything."

This notion of inferiority reflects the hegemony of expert knowledge in Nepal, explored by Nightingale (2005), and is similar to Rest's findings from Arun Valley, where people have been living in uncertainty over a hydropower project for over 25 years: After a conversation with a woman who described herself and her people as "not educated" and without "enough brainpower", Rest reflected,

This conversation is paradigmatic for many encounters I had [...]. Not only for the evident lack of information about the project, but also for putting the blame about this on themselves: as if someone had told her the whole thing but she had just been too ignorant to understand (2014, p. 143).

We argue that people's acceptance of their perceived incapacity should not be confused with indifference towards the project and its impacts on their existence. Rather, it reflects the manifestation of caste and class in Nepali society, where the 'subaltern' have been deprived of any power to influence mainstream discourses. As Ninglekhu (2020) concludes in a magazine article about the three settlements: "The 'subaltern' can speak, but not in a language that the 'mainstream' has ever attempted to learn and understand." It is precisely for the purpose of decoding this 'language' that Svarstad and Benjaminsen (2020, p. 5) emphasize a "senses of justice" approach as a crucial element of recognition in order to "gain access to 'hidden transcripts'" and amplify subaltern voices, as we elaborate in the next sub-chapter.

\section{A lack of benefits from development}

One aspect of Svarstad and Benjaminsen's 'senses of justice' is the notion of 'sense of place' (Barron, 2017; McKittrick, 2011), which describes the attachment that residents have to their area. This connection also became apparent among people in TB, despite the frustration over continued lack of access to basic facilities: "We were born on this land, raised on this land" and "When I travel elsewhere, I feel suffocated. I'm raring to get back home, because we have trees, shade, and it's so relaxing to sit under the tree in the summer."

Surrounded by dense forest and clear streams, TB is indeed exceptionally scenic, but as described earlier, its unspoiled character also represents its exclusion from the perceived benefits of development that occurred in nearby areas, as a villager pointed out: "The people downhill, who came 20 years after us, their place is more developed than ours." For many respondents, SIA promises an end to this limbo, and the abandonment of their homeland is a sacrifice worth making: "We won't get any development here, that's why we're saying the airport should be built. [...] We'll be relocated to another spot, and get what we need, right? Our access to development will no longer be blocked, right?"

However, while several respondents expressed similar hopes that come with resettlement, some conceded that ultimately the government and people in nearby peri-urban areas would benefit far more from the airport: "The landowners, people who can open up companies and hotels, will benefit. There's never any real benefit for people [like us] who have to work daily to feed ourselves." In fact, landowners and estate agents in Nijgadh have already started to reap the benefits of the "fictitious commodity" SIA, as land values have risen

\footnotetext{
${ }^{16}$ Derogatory term for previously used caste category of the alcohol-drinkers (as opposed to Bahuns that do not drink alcohol for religious reasons), classified by the Civil Code 1854 (Muluki Ain); now Janajati (Jha, 2019).
} 
rapidly since the project was resumed (Ninglekhu, 2020). Price increases of $2000 \%$ in just a few years were reported, starting at around 50 US\$ per sq. $\mathrm{m}$ on the outskirts of Nijgadh and more than ten times that along the main road. Enabled by neoliberal land policies and fueled by promises about the economic potential of SIA, land in Nijgadh, similar to the plots in Figure 6, has become a precious commodity among members of the affluent middle and upper-class from Kathmandu (Ninglekhu, 2020); a trend we ourselves observed during our stay in a hotel in Nijgadh, where we saw new groups arriving from Kathmandu every day and overheard many conversations about land prices, sizes and locations.

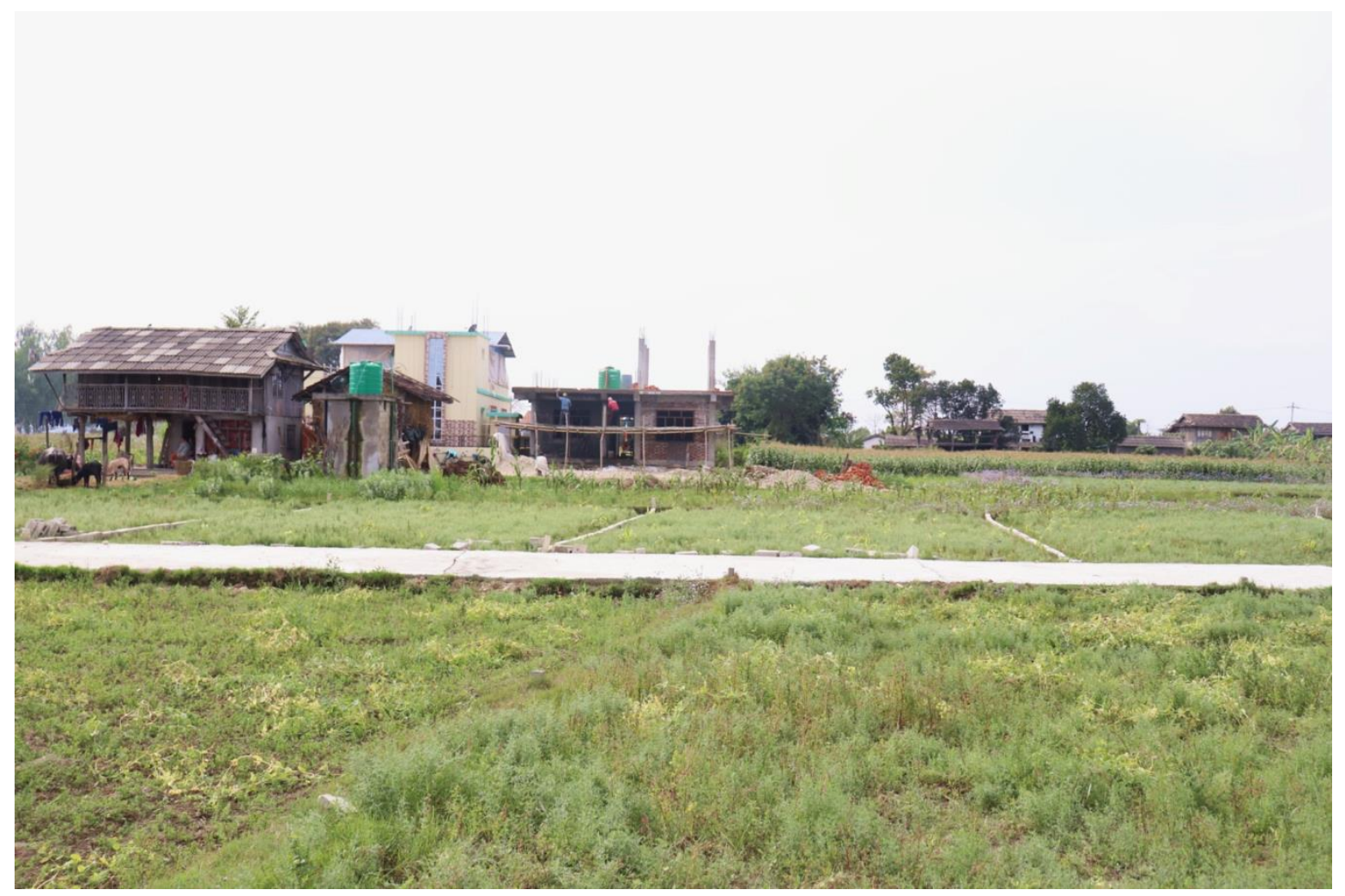

Figure 6: Plotted land areas at the outskirts of Nijgadh. Source: Authors, 2020

In an attempt to secure their basic livelihoods and to not be excluded yet again from the dream of bikas, the inhabitants of TB under the leadership of the Tangiya Basti Concern Committee (2017) have formulated seven demands with regards to their resettlement, listed in Figure 7. The press release of 29 July 2017 stressed that "land must be made available to the locals in the form of redistribution and not in the form of financial compensation." This compensatory land should be in close proximity of the airport project site (demand B). Respondents justified this with the hope for employment opportunities and increased economic activity - a hope that appears greater than the fear of noise pollution.

The project authorities have not formally responded to date, although they repeatedly assured that arrangements will be made: "they told us that they won't make us cry and they would manage and provide facilities. But it isn't in written form." So, the overshadowing state of uncertainty about what the future will look like remains as described by an activist in Kathmandu: 
They'll probably get better schools. But their living conditions will be completely destroyed. They have been living within nature where everything is so surreal and clean. [...] They have no idea where they'll be relocated. Whether everyone will be in one place or whether they will be kept in different areas.

\section{List of demands of Tangiya Basti Concern Committee}

A Land of 2 bigha 5 katha per family should be made available.

[Bigha and katha are customary measurement units in southern Nepal. 2 bigha 5 katha equals $15,238.41 \mathrm{~m}^{2}$ ]

B Compensation areas should be provided within a distance of $3 \mathrm{~km}$ from the border of the project area.

C One employment opportunity per household should be guaranteed in connection with the construction and operation of SIA.

D Rations of food and other essentials should be provided for up to 18 months after the resettlement, while compensatory land is cultivated.

E Physical infrastructure (drinking water, electricity, roads, schools, health post etc.) should be provided at the place of relocation.

F The costs of resettlement and reconstruction of houses must be borne by the government and households must be allowed to take materials from their current structures.

G Development work and the expansion of facilities for humanitarian needs in this area, which were halted before the project became operational, should no longer be hindered.

Figure 7: Translation of list of demands presented by the Tangiya Basti Concern Committee on 29 July 2017. Source: Tangiya Basti Concern Committee, 2020.

The authorities' techno-bureaucratic top-down attitude, once again, reflects the nonrecognition of the communities, of their sense of place, and their socio-cultural institutions. Furthermore, also in view of other development-induced displacement processes in Nepal (Domènech et al., 2013; Rest, 2014), it highlights the urgent need for more deliberative approaches to governance at the community level (Banjade \& Ojha, 2011; Cameron \& Ojha, 2007).

\section{A lack of representation in the media}

Fraser (2000) and Schlosberg (2004) agree that the nonrecognition of communities in the course of socio-environmental interventions leads to their continued marginalization, also with regards to distribution and participation. Here, it is not only project stakeholders who may fail to recognize communities, but also discourse-shaping actors like the media. Initially, we struggled to find information about the affected settlements in the media; and even on social media, we noticed the predominance of content focusing on the ecological impacts of the project. This made us wonder whether this is an indication of broader discursive patterns in the reporting of the SIA.

When inquiring in TB about media coverage, some indicated that they felt misrepresented or ignored. One respondent stated, "they only talk about the trees", while another villager was particularly frustrated by the incomplete reporting: 
They only talk about Nijgadh Airport. Sometimes they mention the village but never in the headlines. There are actually 1,476 houses here [...] but the newspapers always report it carelessly [...] Some say there are only 200 houses. [...] They label us as slum dwellers. [...] If they want to publish correct information they have to come here. The reporters go to Nijgadh because they think that's where the airport is built. That's why no truth comes out.

Overall, our analysis shows that the affected communities only occupy a peripheral place in the English language media coverage of the airport project. Apart from a few exceptions ${ }^{17}$, news agencies rarely address social impacts of the project, seldom bring local voices to the fore, and don't provide information about the historical and cultural background of the communities. This reflects the nonrecognition of the communities and their struggle, and contributes to their invisibility. Combined with the focus on environmental impacts of the project, this may further divert major debates from social justice issues and bury a more nuanced understanding of the conflict under the dichotomy of 'building the airport' vs. 'saving the forest', thus shaping the way discourses on SIA are produced. Furthermore, with regard to Svarstad and Benjaminsen's (2020) critical knowledge production, the media become an unsuitable source of information for the residents, which increases the dependence on private internal or external sources of information, with its own biases and interests.

\section{Power dimensions of conflict}

\section{Structural (Neo-Marxist) power}

The lack of recognition of the communities concerned and their stakes in the airport project is a central theme of our analysis and is representative of their nonrecognition as equal members of Nepali society. As predominantly landless Janajatis, they are at the bottom of Nepal's societal power pyramid, shaped by complex caste and class relations, as land is still a key determinant of "wealth, power and social prestige" in Nepal (Biswakarma, 2018, p. 52). In this "social monopoly of land", "the less land the poor own, the more dependent they become on those who control it" (N. R. Shrestha \& Conway, 1996, p. 321), or as more generally expressed by Svarstad et al. (2018, p. 354), "structure generates the potential and limits for the exertion of power."

The lack of adequate social and environmental regulations to assure the common good and land rights illustrates the distinct power asymmetries between state and landless groups from a class perspective. With no or very small land holdings in their hilly homeland, TB's founders depended on the government's goodwill to let them secure their livelihoods as taungya tree planters and have since lived in fear of looming displacement. With the continued denial of land rights and the ban on further conversion of forest into farmland, the socioeconomic condition of the communities has stagnated for decades. While, with the revival of the SIA project, surrounding communities have profited from the speculative land market and increasing land values, the landless residents again depend on the government's goodwill to relocate them as they don't have the means to do so themselves. One villager expressed: "We're ready to die. We have nowhere to go. It's better to die."

\section{Actor-oriented power}

Bounded by structural forces, the communities' existential struggle for recognition and social status is also shaped by the exertion of power by specific actors and decision-making processes (Svarstad et al., 2018). One example is the persistent denial of basic facilities. In a process of convoluted negotiations over the access to electricity, Bara's Chief District Officer (CDO) ultimately used his 'power resources' to deny the settlements access to the regional grid, thus siding with SIA project managers. Another example is the decision-making process on the resettlement locations. While the TBSS leaders were shown several locations in November 2019, the SIA project manager, whom we interviewed about possible resettlement sites, was clear that the decision would be taken top-down: "We only followed orders from above. We send them suggestions and data. Decisions must be data-driven. These are all internal matters."

17 For example, The Record Nepal, a Kathmandu-based digital magazine has published in-depth articles about the settlements. 
Political ecologist often see resistance of local communities as a counterforce to political or corporate actors. In this case, however, the resistance of the residents is limited by their fragile dwelling situation. Although many seemed determined to fight for their demands - "We will protest against [the government]" the government holds its leverage through the threat of forced eviction. Furthermore, the communities lack external support and allies who could advocate their demands without fear of retaliation. Our analysis shows that this is partly because the airport opposition largely builds on conservationist narratives that frame the villagers as encroachers and it promotes a 'fortress conservation' approach, "where urban elites call for the enclosure of lands long used and occupied by [...] local people, all in the name of protection" (Peet et al., 2010, p. 27). As one activist admitted:

Even if the airport doesn't get made there, I think the [TB] people irrespectively will get relocated. [...] Because even if you want to turn this into a protected area, there shouldn't be, there cannot be villages [...] And it's really sad for them but that's how it is.

The same activist explained that while she had initially planned to call attention to the villagers' situation, she realized that because of the communities' landless status, it would be extremely difficult to define actual rights violations: "As evident as it is, [...] Tangiya Basti people, their condition, it won't hold for our case." Ultimately, both PILs against SIA are based almost entirely on environmental concerns.

\section{Post-structuralist power: Discursive power}

Finally, the production and circulation of powerful narratives strengthen structures and legitimize actors' decisions. In the present case, several discourses are shaping the struggle of local communities.

The government has repeatedly presented the SIA project as a guaranteed development path, although its feasibility remains questionable because, as far as is known, no detailed market analysis has been conducted. Here, typical for developmentalism in the Nepali context, an infrastructure project is directly linked to national prosperity; SIA as a 'National Pride Project.' With the desire for bikas permeating all levels of society, questioning a project like SIA can be seen as 'anti-development' and therefore 'anti-national.' This was also evident in TB, when respondents insisted that they knew of the national benefits the project would bring: "It's a work of development. The country will have an income from it, [...] because [of that] the airport should be built." Although they want their demands met through a type of governmentality, many expressed the need to make personal sacrifices in the name of development: "We love our nation. If the airport project is a success, it means that our village will be destroyed", and "We have to lose something to gain something." Linking development to patriotism further weakens the communities' power to resist and their struggle for justice. Not only are they confronted with government retaliation for their protest, but they also risk being portrayed as 'antinationalists' which further deteriorates their already vulnerable position in Nepali society.

Since most villagers are not indigenous to the area ${ }^{18}$, their struggle for livelihoods is further delegitimized by portraying them as 'encroachers' and questioning their claim to the land they inhabit, as previously illustrated. Only $50 \mathrm{~km}$ north of Nijgadh, the resistance of an indigenous Newari community to the Fast Track Road Project ${ }^{19}$ was much stronger, as evidenced by extensive media coverage, since their struggle was based on their cultural-historical connection to their land and the preservation of Newari culture as a national good (Manandhar, 2018; Subedi, 2019).

The narrative of 'illegal encroachment', causing the degradation of forest resources, also unites pro and anti-airport groups. As Shrestha and Conway (1996, p. 315) argue: "land encroachment [...] situates landless peasants in a position of direct conflict [...] with the Nepalese State and its vested class interests which, over the past few years, are camouflaged as environmentalism." This conflation of state-led developmentalist and

\footnotetext{
${ }^{18}$ With the exception of 80 Tharu households in KG.

${ }^{19}$ The 72.5 km long Kathmandu-Terai Fast Track, another 'National Pride Project' that is currently under construction, will act as a direct link between the capital and Nijgadh, reducing travel time from five hours to one hour (Khatiwada \& Aryal, 2019; Shakya, 2019).
} 
airport-opposition-led conservationist narratives illustrates the discursive power asymmetries towards local communities, rendering them invisible. It also reveals a tension between environmental and social justice struggles, where claims to nature are pitted against community interests, impeding a nuanced discussion of either.

\section{Conclusion}

We have aimed to provide insights into the complex forces that shape the everyday struggles for justice and livelihoods of communities affected by the construction of Nepal's Second International Airport. We show how the misrecognition of residents' interests and lived realities, particularly in Tangiya Basti, is closely intertwined with past and present distributive and procedural injustices and reinforced by power asymmetries of various types and scales. We argue that the villagers' social subordination was manifested with the failure of the government to grant land rights, long before the airport project was launched. Their status as landless, predominantly Janajati, migrant population has since not only undermined their inclusion as stakeholders in the airport project and their demands for basic facilities; it also fueled narratives of portraying them as 'illegal encroachers' used by dominant actors to further delegitimize the communities, which contributes to their invisibility in major debates.

Villagers maneuver their sense of belonging, their peasant identity, their desire for bikas and a less troublesome future for their children, their disillusionment with the government, their hope for fair compensation, their struggle for just treatment, their patriotism, and their compliance with government decisions. These contradictory notions, which emerged even within individual interviews, have one commonality: uncertainty, underlining the temporality of local livelihoods.

In our analysis, we have combined justice theories and conceptualizations of power from political ecology with notions of a sense of justice and critical knowledge production. We have explored competing justice claims around the airport project, which is predominantly framed as purely a conflict over natural resources. We show that at the community level, claims to social justice and socio-economic security outweigh claims to nature; in part because the 25 -year-long project limbo has led to a diminished sense of place. These social justice concerns contrast with environmental justice claims put forward by urban airport opponents.

Overall, we understand the SIA project conflict to be shaped by powerful development and conservation narratives that do not provide an adequate platform for community voices. Our research suggests that further investigation of the impact of large infrastructure projects on local livelihoods and potential tensions between competing justice claims of stakeholders is needed in the context of Nepal and other regions of South Asia. This must include more nuanced investigations of micro-level dynamics along caste, class, and gender lines. Ultimately, our research highlights the need to explore larger questions of reconciling community interests with sustainability and sustainable development concerns; with deliberative democracy approaches offering potential entry points.

\section{References}

Adhikari, L., \& Poudel, D. (2018, November 15). Agroforestry: Healing the land use problem in Nepal. A Blog by Dikshit Poudel. https://poudeldikshit.wordpress.com/2018/11/15/agroforestry-healing-the-land-useproblem-in-nepal/

Ahearn, L. M. (2004). Invitations to Love: Literacy, love letters, and social change in Nepal. Adarsh Books.

Amatya. (2018). Agroforestry systems and practices in Nepal-Revised Edition. Agriculture and Forestry University.

Ascher, W., \& Krupp, C. (2010). Rethinking physical infrastructure development. In W. Ascher \& C. Krupp (Eds.), Physical infrastructure development: Balancing the growth, equity, and environmental imperatives (pp. 1-33). Palgrave Macmillan. https://doi.org/10.1057/9780230107670_1

Awale, S. (2020, January 5). Pandemic impact on aviation may kill Nijgad. Nepali Times. https://www.nepalitimes.com/here-now/pandemic-impact-on-aviation-may-kill-nijgad/

Bachmann, G. (2019, December 4). Umweltproteste in Nepal: Von wegen Flugscham. Die Wochenzeitung. https://www.woz.ch/-a31f 
Banjade, M. R., \& Ojha, H. (2011). Facilitating deliberative governance: Innovations from Nepal's community forestry program - a case study in Karmapunya. The Forestry Chronicle. https://doi.org/10.5558/tfc81403-3

Barron, M. (2017). Remediating a sense of place: Memory and environmental justice in Anniston, Alabama. Southeastern Geographer, 57(1), 62-79. https://doi.org/10.1353/sgo.2017.0006

Bhattarai, B. (2020, July 5). Case study from Nijgadh Airport, Nepal. Airport Conflicts - Struggles for Environmental Justice, online. https://stay-grounded.org/wp-content/uploads/2020/07/AirportConflicts-\%E2\%80\%93-Struggles-for-Environmental-Justice.pdf

Bhattarai, K. D. (2019a, December 14). Nijgadh International Airport: Still in limbo after 25 years. The Annapurna Express. https://theannapurnaexpress.com/news/nijgadh-international-airport-still-inlimbo-after-25-years-2095

Bhattarai, K. D. (2019b, December 28). Is Nepal's new airport dream an environmental nightmare? The Diplomat. https://thediplomat.com/2019/12/is-nepals-new-airport-dream-an-environmental-nightmare/

Bhusal, K. (2010, March 19). Taungya and shifting cultivation system in Nepal. Forestry. http://forestrycomponents.blogspot.com/2010/03/taungya-and-shifting-cultivation-system.html

Biswakarma, T. (2018). Citizenship and social security of landless Dalits in Nepal. Globe: A Journal of Language, Culture and Communication, 6, 52-65.

Breeding, M. E. (2011). The micro-politics of vote banks in Karnataka. Economic and Political Weekly, 46(14), $71-77$.

Bridger, R. (2019, February 18). Nijgadh Airport and Airport City, Nepal. Environmental Justice Atlas. https://ejatlas.org/conflict/nijgadh-airport-and-aerotropolis

Cameron, J., \& Ojha, H. (2007). A deliberative ethic for development: A Nepalese journey from Bourdieu through Kant to Dewey and Habermas. International Journal of Social Economics, 34(1/2), 66-87. https://doi.org/10.1108/03068290710723372

Campbell, B. (2010). Rhetorical routes for development: A road project in Nepal. Contemporary South Asia, 18(3), 267-279. https://doi.org/10.1080/09584935.2010.501099

Chernaik, M. (2019). On biological resources permanently lost to the Second International Airport Project in Kohalbi Municipality in Bara District of Province 2. Environmental Law Alliance Worldwide U.S.

CJ Rana: Stay on Nijgadh Airport to assess environmental impact of project. (2020, March 1). OnlineKhabar. https://english.onlinekhabar.com/cj-rana-stay-on-nijgadh-airport-to-assess-environmental-impact-ofproject.html

Construction of Nijgadh Airport should not be delayed: PM Deuba. (2022, January 6). Online Radio Nepal. https://onlineradionepal.gov.np/2022/01/06/240136.html

Dhakal, A. (2018, September 26). What are the prevailing problems in Nijgadh Airport EIA? Hakahaki - Face to Face Portal. http://www.hakahakionline.com/en/5229/what-are-the-prevailing-problems-in-nijgadhairport-eia/

Dhakal, S. (2011). Land tenure and agrarian reforms in Nepal. Community Self Reliance Centre. https://agris.fao.org/agris-search/search.do?recordID=US201300003478

Dhungana, B. (2019a, July 18). Life in limbo for the residents of Tangia Basti. The Record. https://www.recordnepal.com/wire/photo-essays/life-in-limbo-for-the-residents-of-tangia-basti/

Dhungana, B. (2019b, July 26). Nijgadh International. The Record. https://www.recordnepal.com/wire/videos/nijgadh-international/

Domènech, L., March, H., \& Saurí, D. (2013). Contesting large-scale water supply projects at both ends of the pipe in Kathmandu and Melamchi Valleys, Nepal. Geoforum, 47, 22-31. https://doi.org/10.1016/j.geoforum.2013.02.002

Escobar, A. (1995). Encountering development: The making and unmaking of the Third World. Princeton University Press.

Fernholz, R. M. (2010). Infrastructure and inclusive development through "Free, Prior, and Informed Consent" of Indigenous Peoples. In W. Ascher \& C. Krupp (Eds.), Physical infrastructure development: balancing 
the growth, equity, and environmental imperatives (pp. 225-258). Palgrave Macmillan. https://doi.org/10.1057/9780230107670_9

Fraser, N. (1998). Social justice in the age of identity politics: Redistribution, recognition, participation. FS I 98-108; Discussion Papers, Research Unit: Organization and Employment. WZB Berlin Social Science Center. https://ideas.repec.org/p/zbw/wzboem/fsi98108.html

Fraser, N. (2000). Rethinking recognition. New Left Review, 3. https://newleftreview.org/issues/II3/articles/nancy-fraser-rethinking-recognition

Fraser, N. (2005). Reframing Justice in a Globalizing World. New Left Review, 36, 1-19.

Gahatraj, S. (2017, October 12). Sustainable farming: Agro-forestry in Nepal. The Himalayan Times. https://thehimalayantimes.com/opinion/sustainable-farming-agro-forestry-nepal/

Gautam, S. (2020, February 13). Nijgadh: Prospects and priorities. The Record. https://www.recordnepal.com/perspective/nijgadh-prospects-and-priorities/

GEOCE. (2018). Environmental Impact Assessment (EIA) of Second International Airport Project. GEOCE Consultants (P) Ltd.

Ghimire, B. (2022, January 6). Despite current calm, standoff in Supreme Court portends larger complications. The Kathmandu Post. https://kathmandupost.com/national/2022/01/06/despite-current-calm-standoffin-supreme-court-portends-larger-complications

Golf, T. (2017, September 6). Tourism \& Civil Aviation Ministry signs MoU with Nepal Army for Nijgadh International Airport. Aviation Nepal News Network. https://www.aviationnepal.com/tourism-civilaviation-ministry-signs-mou-with-nepal-army-for-nijgadh-international-airport/

Gonzalez, A. (2019). Making "a racket" but does anybody care? A study of environmental justice access and recognition through the political ecology of voice. Geoforum, 102, 142-156. https://doi.org/10.1016/j.geoforum.2019.03.024

Islar, M. (2012). Struggles for recognition: Privatisation of water use rights of Turkish rivers. Local Environment, 17(3), 317-329. https://doi.org/10.1080/13549839.2012.665858

Islar, M. (2013). Private Rivers: Politics of renewable energy and the rise of water struggles in Turkey [LUCSUS]. https://portal.research.lu.se/portal/en/publications/private-rivers-politics-of-renewableenergy-and-the-rise-of-water-struggles-in-turkey(94566e62-073a-4654-95987cf61d1dbf93)/export.html

Jacobson, L., Åkerman, J., Giusti, M., \& Bhowmik, A. K. (2020). Tipping to staying on the ground: Internalized knowledge of climate change crucial for transformed air travel behavior. Sustainability, 12(5), 1994. https://doi.org/10.3390/su12051994

Jha, H. B. (2019). The Janajati of Nepal (p. 108). Vivekanda International Foundation. https://www.vifindia.org/sites/default/files/Janjatis-in-Nepal.pdf

Khatiwada, S., \& Aryal, R. (2019). Effective implementation of the "Kathmandu-Terai Fast Track" Road Project. 8.

Kramer, M. P. (2008). Negotiating modernity: Narratives of change and development among village women in Nepal. Masters thesis. University of Oslo. https://www.duo.uio.no/handle/10852/24387

Lal, A. (2019, July 16). Nijgadh Airport: What is proposed and why environmental analysts are so worried. The Record. https://www.recordnepal.com/category-explainers/nijgadh-airport-what-is-proposed-and-whyenvironmental-analysts-are-so-worried/

Malla, K. P. (2018, November 19). Bahunvada: Myth or reality? Himal Southasian. https://www.himalmag.com/bahunvada-myth-or-reality-kamal-p-malla-1992/

Manandhar, S. (2018, March 19). Fast Track brings fear of displacement to Khokana. The Record. https://www.recordnepal.com/wire/fast-track-brings-fear-of-displacement-to-khokana/

Mandal, C. K. (2020, July 2). How many trees needed to make way for Nijgadh? Ministry orders fresh count to settle issue. The Kathmandu Post. https://kathmandupost.com/climate-environment/2020/02/07/howmany-trees-needed-to-make-way-for-nijgadh-ministry-orders-fresh-count-to-settle-issue

McKittrick, K. (2011). On plantations, prisons, and a black sense of place. Social \& Cultural Geography, 12(8), 947-963. https://doi.org/10.1080/14649365.2011.624280 
Ministry of External Affairs. (2018, July 4). English translation of press statement by Prime Minister during the State Visit of Prime Minister of Nepal (April 07, 2018). MEA Media Center. https://www.mea.gov.in/Speeches-

Statements.htm?dtl/29798/English+Translation+of+Press+Statement+by+Prime+Minister+during+the + State+Visit+of+Prime+Minister+of+Nepal+April $+07+2018$

Mulmi, A. R. (2018, January 6). A story called bikas. The Kathmandu Post. https://kathmandupost.com/opinion/2018/06/01/a-story-called-bikas

Murton, G., \& Lord, A. (2020). Trans-Himalayan power corridors: Infrastructural politics and China's Belt and Road Initiative in Nepal. Political Geography, 77, 102100. https://doi.org/10.1016/j.polgeo.2019.102100

National Planning Commission. (2020). 15th Plan (FY 2076/77-2080/81). Government of Nepal. https://www.npc.gov.np/images/category/15th_Plan_Final1.pdf

Ndomba, O. A., Bakengesa, S., Petro, R., Maguzu, J., Chamshama, S. a. O., Kiimu, H. R., \& Lema, M. (2015). Perils of Taungya to the productivity of forest plantations and need for modification: Case study of Meru Forest Plantation in Tanzania. International Journal of Agriculture and Forestry, 5(5), 267-275.

NEFEJ. (2019). Report on Environmental, Social and Economic Impacts of Second International Nijgadh Airport. Nepal Forum of Environmental Journalists. https://nefej.org.np/1043/

Nightingale, A. J. (2005). "The Experts Taught Us All We Know": Professionalisation and knowledge in Nepalese community forestry. Antipode, 37(3), 581-604. https://doi.org/10.1111/j.00664812.2005.00512.x

Nightingale, A. J. (2010). A Forest Community or Community Forestry? Beliefs, meanings and nature in northwestern Nepal. In A. Guneratne (Ed.), Culture and the Environment in the Himalaya (pp. 79-99). Routledge.

Nightingale, A. J. (2017). Power and politics in climate change adaptation efforts: Struggles over authority and recognition in the context of political instability. Geoforum, 84, 11-20. https://doi.org/10.1016/j.geoforum.2017.05.011

Nightingale, A. J., \& Ojha, H. R. (2013). Rethinking power and authority: symbolic violence and subjectivity in Nepal's Terai Forests. Development and Change, 44(1), 29-51. https://doi.org/10.1111/dech.12004

Ninglekhu, S. (2020, July 22). For the airport yet to come. The Record. https://www.recordnepal.com/wire/features/for-the-airport-yet-to-come/

Ojha, D. P. (1983). History of land settlement in Nepal Tarai. CNAS Journal, 11(1), 21-44.

Otsuki, K., Zoomers, A., \& Shannon, M. (2016, February 6). Large scale investments in infrastructure: Competing policy regimes to control connections. Conference paper: Global governance/politics, climate justice \& agrarian/social justice: linkages and challenges, Den Haag. https://www.researchgate.net/publication/333056119_Large_Scale_Investments_in_Infrastructure_Co mpeting Policy regimes to Control_Connections

Ottinger, G. (2017). Opening black boxes: Environmental justice and injustice through the lens of science and technology studies. In Holifield, R., Chakraborty, J., \& Walker, G. (Eds.) The Routledge Handbook of Environmental Justice. Routledge.

Paudel, D. (2016). The double life of development: Empowerment, USAID and the Maoist uprising in Nepal. Development and Change, 47(5), 1025-1050. https://doi.org/10.1111/dech.12262

Paudyal, M., \& Koirala, K. R. (2018, November 10). "Not a single tree more than absolutely necessary will be cut down for Nijgadh airport." República. http://myrepublica.nagariknetwork.com/news/51648/

Peet, R., Robbins, P., \& Watts, M.J. (eds.) (2010). Global Political Ecology. Routledge.

Persson, S., Harnesk, D., \& Islar, M. (2017). What local people? Examining the Gállok mining conflict and the rights of the Sámi population in terms of justice and power. Geoforum, 86, 20-29. https://doi.org/10.1016/j.geoforum.2017.08.009

Pigg, S. L. (1992). Inventing social categories through place: Social representations and development in Nepal. Comparative Studies in Society and History, 34(3), 491-513. 
Pigg, S. L. (1993). Unintended consequences: The ideological impact of development in Nepal. South Asia Bulletin, 8(1\&2), 45-58.

Pradhan, D. P. N., Kansakar, A. J., \& Poudel, A. (2019). Development of Nijgadh International Airport at Bara. Pradhan \& Associates. http://www.pradhanlaw.com/client-briefing/development-of-nijgadhinternational-airport-at-bara

Pradhan, T. R. (2019, June 12). Supreme Court asks government to halt plans for Nijgadh airport. The Kathmandu Post. https://kathmandupost.com/province-no-2/2019/12/06/supreme-court-asksgovernment-to-halt-plans-for-nijgadh-airport

Prasain, S. (2020a, May 3). Zurich International asks for extension following court order to stop felling trees at Nijgadh. The Kathmandu Post. https://kathmandupost.com/national/2020/03/05/zurich-internationalasks-for-extension-following-court-order-to-stop-felling-trees-at-nijgadh

Prasain, S. (2020b, September 15). Decision to prepare an "updated" master plan for Nijgadh airport meets with criticism. The Kathmandu Post. https://kathmandupost.com/national/2020/09/15/decision-to-preparean-updated-master-plan-for-nijgadh-airport-meets-with-criticism

Prasain, S. (2021, March 2). Government backs plan to build Nijgadh airport. The Kathmandu Post. https://kathmandupost.com/money/2021/02/03/government-backs-plan-to-build-nijgadh-airport

Pro Public. (2019, December 15). ProPublic 2019: Community dialogues, campaign victory, and the Nijgadh protests. Voices from FoE Asia Pacific. https://foeasiapacific.org/2019/12/15/propublic-2019community-dialogues-campaign-victory-and-the-nijgadh-protests/

Rai, P. (2019, May 25). The construction work of Nijgadh International Airport fails to boost up. Aviation Nepal. https://www.aviationnepal.com/the-construction-work-of-nijgadh-international-airport-fails-toboost-up/

Rest, M. (2012). Generating power: Debates on development around the Nepalese Arun-3 hydropower project. Contemporary South Asia, 20(1), 105-117. https://www.zora.uzh.ch/id/eprint/75169/1/Rest_Generating_power.pdf

Rest, M. (2014). Water power: Controversies on development and modernity around the Arun-3 hydropower project in Nepal. In Rest, M. Water power: Controversies on development and modernity around the Arun-3 hydropower project in Nepal. $\mathrm{PhD}$ Dissertation, University of Zurich. https://doi.org/10.5167/uzh-109721

Robbins, P. (2011). Political ecology: A critical introduction (2nd edition). Wiley-Blackwell.

Sah, L. (2019, December 19). Nepal needs another international airport. So why is Nijgadh being held up? The Kathmandu Post. $\quad$ https://kathmandupost.com/province-no-2/2019/12/19/nepal-needs-anotherinternational-airport-so-why-is-nijgadh-being-held-up

Saxer, M. (2013). Between China and Nepal: Trans-Himalayan trade and the second life of development in Upper Humla. Cross-Currents: East Asian History and Culture Review, 8, 31-52.

Schlosberg, D. (2004). Reconceiving environmental justice: Global movements and political theories. Environmental Politics, 13(3), 517-540. https://doi.org/10.1080/0964401042000229025

Schlosberg, D. (2007). Defining environmental justice: theories, movements, and nature. Oxford University Press. https://doi.org/10.1093/acprof:oso/9780199286294.001.0001

Schlosberg, D. (2013). Theorising environmental justice: The expanding sphere of a discourse. Environmental Politics, 22(1), 37-55. https://doi.org/10.1080/09644016.2013.755387

Shah, S. G. (2019). An analysis of EIA report of the Second International Airport Project, Nepal. Hydro Nepal: Journal of Water, Energy and Environment, 24, 57-67. https://doi.org/10.3126/hn.v24i0.23585

Shahi, I. (2019, March 18). Nijgadh Airport to be catastrophic for Nepal's tiger and elephant populations. The Record. https://www.recordnepal.com/wire/features/nijgadh-airport-to-be-catastrophic-for-nepalstiger-and-elephant-populations/

Shakya, P. (2019, December 18). Kathmandu-Terai/Madhesh Fast Track Road Project, Nepal. Environmental Justice Atlas. https://ejatlas.org/conflict/kathmandu-terai-madhesh-fast-track-road-project-nepal

Sharma, S. (2002). Introductory chapter: Half a century of foreign aid. In Sharma, S. Foreign Aid and Politics in Nepal: A Case Study. Himal Books. 
Shrestha, K. D. (2020, September 18). Zurich Airport International opts out of Nepal project. Nepali Times. https://www.nepalitimes.com/here-now/zurich-airport-international-opts-out-of-nepal-project/

Shrestha, N. R., \& Conway, D. (1996). Ecopolitical battles at the Tarai Frontier of Nepal: An emerging human and environmental crisis. International Journal of Population Geography, 2(4), 313-331. https://doi.org/10.1002/(SICI)1099-1220(199612)2:4<313::AID-IJPG40>3.0.CO;2-K

Shrestha, S. (2018). Strategy paper "Nijgadh Airport."

Srinivas, M. N. (1951). The social structure of a Mysore Village. Economic and Political Weekly, 3(42-43), $7-$ 8.

Subedi, K. (2019, August 28). Nepal Army changes Fast Track alignment, historical Khokana to be preserved. My Republica. http://myrepublica.nagariknetwork.com/news/73174/

Sunuwar, M. (2021, May 30). Government aims to operate new international airports in the next fiscal year. My Republica. http://myrepublica.nagariknetwork.com/news/111587/

Svarstad, H., \& Benjaminsen, T. A. (2020). Reading radical environmental justice through a political ecology lens. Geoforum, 108, 1-11. https://doi.org/10.1016/j.geoforum.2019.11.007

Svarstad, H., Benjaminsen, T. A., \& Overå, R. (2018). Power theories in political ecology. Journal of Political Ecology, 25(1), 350-363. https://doi.org/10.2458/v25i1.23044

Tangiya Basti Concern Committee. (2017). Tangiya Basti Concern Committee, Jitpur Simara Submunicipality-16, Bara Tangiya Basti Press release.

Thakur, R. K. (2015). Geospatial modeling of walk trails of Asian Elephant Elephas maximus as tool for mitigating human elephant conflicts in Central Nepal. The Rufford Foundation. https://www.rufford.org/files/17279-1\%20Final\%20Report.pdf

Timperley, J. (2019, October 9). Why 'flight shame' is making people swap planes for trains. BBC Future. https://www.bbc.com/future/article/20190909-why-flight-shame-is-making-people-swap-planes-for$\underline{\text { trains }}$

Wagley, M., \& Ojha, H. (2002). Analyzing participatory trends in Nepal's Community Forestry (pp. 122-142). ForestAction Nepal and IGES, Japan. https://www.iges.or.jp/en/publication_documents/pub/policyreport/en/180/09_Nepal.pdf

Wickeri, E. (2011). "Land is Life, Land is Power": Landlessness, exclusion, and deprivation in Nepal. Crowley Mission Reports. https://ir.lawnet.fordham.edu/crowley reports/2

Yin, R. K. (2009). Case study research: Design and methods. SAGE.

Young, I. M. (2002). Inclusion and democracy. Oxford University Press. https://doi.org/10.1093/0198297556.001.0001 